\title{
Assessing the Efficacy of Seedling Planting as a Forest Restoration Technique in Temperate Hardwood Forests Impacted by Invasive Species
}

\author{
Michaela J. Woods ${ }^{1}$, Meredith Cobb ${ }^{2}$, Katie Hickle ${ }^{1}$ and Ryan W. McEwan ${ }^{1, *}$ \\ 1 Department of Biology, University of Dayton, Dayton, OH 45469, USA \\ 2 Five Rivers Metroparks, 409 E. Monument Ave, Dayton, OH 45402, USA \\ * Correspondence: ryan.mcewan@udayton.edu; Tel.: +1-937-229-2558
}

Received: 23 July 2019; Accepted: 16 August 2019; Published: 18 August 2019

check for updates

\begin{abstract}
The emerald ash borer (Agrilus planipennis Fairmaire; EAB) is an invasive insect that causes mortality of trees in the genus Fraxinus, creating canopy gaps that may facilitate invasion by exotic plants. Planting native tree seedlings under EAB-infested Fraxinus may accelerate succession and preclude invasive plant expansion; however, the effectiveness of this approach has not been experimentally tested. We assessed understory seedling planting of Quercus rubra, Carya laciniosa, and Juglans cinerea in EAB-infested forests, where the invasive shrub Lonicera maackii (Amur honeysuckle) was removed. We tested whether the use of plastic tree shelters ("tree tubes") or planting season (fall versus spring) contributed to the success of the reforestation plan by measuring growth rates $(\mathrm{cm} / \mathrm{yr})$ and survivorship two and seven years after planting. After seven years, seedling survivorship was $<25 \%$ for all species and planting techniques. Quercus rubra exhibited poor survivorship with one seedling surviving to the conclusion of the experiment. Juglans cinerea and C. laciniosa had higher survivability and growth rates than did Q. rubra after two and seven years. Effects of tree tubes were weak and temporary. After 2 years, Q. rubra seedling survivorship was higher in tree tubes; however, by the end of the experiment 29 of the 30 Q. rubra seedlings in tree tubes had died. Juglans cinerea seedlings grew faster when planted in the fall compared to the spring, but overall survivorship of these seedlings was unaffected by planting season. Neither the use of tree shelters nor the planting season contributed to the growth or survival of C. laciniosa seedlings. In summary, our results indicate that seedling planting of Carya and Juglans may be a useful way to increase biodiversity in regenerating forests; however, the resource-expensive processes of over-wintering seedlings and using tree shelters may not increase the success of reforestation efforts.
\end{abstract}

Keywords: Lonicera maackii; Agrilus planipennis; invasive species; reforestation

\section{Introduction}

Temperate deciduous forests of eastern North America have experienced a series of biological invasions that have necessitated management action aimed at ecological restoration. Many invasive pests, pathogens, and plant species have pulsed through these forests causing extensive tree mortality [1-4]. North American hardwood forests are experiencing warmer and wetter climates, possibly facilitating the establishment and spread of invasive species [5]. These invasions are often concomitant, and some invasive species can facilitate others through "invasional meltdown" [6]. For example, some invasive insects can cause overstory tree mortality creating canopy gaps and high light levels on the forest floor which enables the establishment of new invasive plants and accelerates growth of those which have already established [7-9]. Understory light availability is a good predictor of success for many invasive plants and complex management schemes are required to address the loss of forest canopy trees in areas where invasive plants are already established. 
Lonicera maackii (Amur honeysuckle) is an invasive shrub that dominates many forest understories in eastern and mid-western North America following its naturalization in the mid-1900s [10]. A complex suite of traits has been associated with L. maackii's invasion success and this species is known to strongly influence a wide array of ecosystem properties [11]. Lonicera maackii invasion is associated with a reduction in native shrub and tree seedling success and regeneration in invaded forests [12-14] and removing this shrub from affected ecosystems can promote the recovery of native plants $[13,14]$. Additionally, invasion along stream corridors has strong potential to alter the macroinvertebrate community and influence in-stream ecological processes [15-17]. This species also influences nutrient cycling and other ecosystem processes in forests [18-23]. Allelopathic effects of L. maackii leachate on seed germination have been detected in controlled experiments [24] and invasion of this species is associated with a reduction in native shrub and tree seedling success and regeneration in invaded forests [12-14]. Removing this shrub from affected ecosystems has been shown to promote the recovery of native plants $[13,14]$. Lonicera maackii removal has become a priority for some agencies and clearing followed by tree planting could facilitate successful establishment of native tree species in invaded forests by reducing the amount of immediate competition the trees would receive. Further, if planted trees successfully establish, they may forestall reinvasion. Removing L. maackii and mitigating the potential for re-invasion is particularly important in forests where canopy-opening disturbance is likely to occur, as this species has been shown to be most successful in high-light environments $[25,26]$.

Emerald ash borer (Agrilus planipennis Fairmaire; EAB) infestation has decimated ash trees (Fraxinus species) following its introduction to Michigan in 2002. An invasive beetle with a larval phase that consumes the phloem of ash trees, EAB can cause up to $99 \%$ mortality in infested forest stands [27]. Following EAB infestation, affected ash trees begin thinning and acquire less nutrients and moisture, opening the canopy and increasing light availability [28]. This facilitates an open niche space for species that require similar nutrients and benefit from light availability, which may facilitate new plant invasions or accelerate the growth of those already established in the forest understory. While ash mortality is preceded by canopy thinning, many ash trees can remain standing for several years if they are not manually cut before falling to the forest floor [29]. In closed canopy, secondary forests in southwestern Ohio, less than $1 \%$ of plant cover was invasive where ash trees killed by EAB were left standing, while plant cover consisted of $18 \%$ invasive plant species with manual ash removal [30]. In order to prevent the rapid spread of invasive species and reduce costs of managing ash death, one land management approach has been to allow ash trees to die in place while underplanting tree species replacements to reduce possible competition from invasive plants.

Common co-invasions often become the focus of management plans in EAB-decimated forests, but reforestation efforts can be impacted by many factors including the season of tree planting. In the mid-western United States, spring plantings are usually preferred since there is moist soil and cool air which allows for ideal planting conditions and reduces the likelihood of physiological stress [31]. Spring planting also allows time for seedling dormancy over winter, which reduces the risk of physiological stress during planting and allows seedlings to experience a full growing season prior to being planted in direct competition with other species [32-34]. Alternatively, fall plantings are appealing since they allow the avoidance of physiological damage, desiccation, or depletion of energy that could occur during the winter storage of seedlings by land managers [34]. Specifically, Juglans nigra was not as successful when planted in the fall; yet, Quercus species were not influenced by planting season when planted in a hardwood tree plantation in southeast Indiana [34]. The differential impacts of planting season may indicate species-specific responses that should be evaluated prior to establishing replacement species for ash trees.

A myriad of factors dictate tree seedling success in a forest understory and management actions are often necessary to improve survivorship. Herbivores, such as Odocoileus virginianus (white-tailed deer), constitute a major threat to newly established seedlings. Overabundant $O$. virginianus populations are increasingly common throughout much of eastern North America and over-graze seedlings with strong effects on tree regeneration [35-37]. One management technique used to ameliorate herbivore 
damage is the use of shelters, such as plastic tree tubes, which act as a physical barrier to prevent grazing. Using these tubes is expensive and time consuming, and the efficacy is questionable since they can cause both benefit and harm to seedlings. Seedlings grown in shelters are typically light limited and allocate more energy into height growth than in basal diameter growth which may have long-term implications for sapling morphology $[38,39]$. In many cases, herbivory pressure is strong enough to warrant the use of tree tubes despite the potential detrimental impacts they may have. Indeed, Q. rubra seedlings planted with tree tubes tend to have faster growth rates and higher survivorship than their unsheltered counterparts [40-42] but this is not always the case [43]. Further research is needed to assess the efficacy of the expensive and time-consuming practices of using tree shelters to increase seedling survivorship and performance.

In this project, we sought to assess the tree seedling success in the understory of a forest undergoing rapid loss of Fraxinus due to the presence of $\mathrm{EAB}$ where L. maackii had been removed by measuring tree seedling growth and survival. The Five Rivers Metroparks (FRMP) manages approximately $60 \mathrm{~km}^{2}$ of forest near Dayton, Ohio (USA) and, as a long-term management strategy, sought to maintain forest integrity and biodiversity in the face of dual invasions by EAB and L. maackii. The conservation team at FRMP instituted a plan of removing L. maackii shrubs and planting seedlings underneath Fraxinus trees. In collaboration with FRMP, we experimentally assessed survivorship and performance of three tree species: Carya laciniosa (shellbark hickory), J. cinerea (butternut), and Q. rubra (red oak). These species were selected by land managers at FRMP as target species for reforestation efforts for biological reasons. Carya species make up a significant portion of overstory trees in forests of eastern North America [44] and this genus has been decreasing in prevalence through time in association with a variety of factors including environmental changes caused by climate change [45]. Carya laciniosa is a common species in the overstory at Sugarcreek MetroPark, where this study took place, and has relatively high survivorship in comparison to other native tree seedlings [46], making it a potentially useful target species for replacement of ash trees within EAB-affected regions. We also assessed the success of $Q$. rubra, as it is a prevalent overstory component in regional forests and is common in Sugarcreek MetroPark as a large tree, but the regeneration and recruitment of seedlings has been declining [47-51]. Juglans cinerea, the final species in our experiment, was selected for study because this species is of significant conservation value due to the loss of populations due to the butternut canker disease caused by the fungal pathogen, Sirococcus clavigignenti-juglandacearum [2,52]. Additionally, J. nigra (black walnut) a closely related species, is highly successful in the FRMP habitats, including Sugarcreek MetroPark, which indicates J. cinerea may be successful in these habitats. All three selected species have large fruits, which was an important additional management consideration due to the potential positive effects on wildlife.

In this experiment, we planted seedlings of C. laciniosa, J. cinera, and Q. rubra either in tree tubes or without shelter and either in spring or fall seasons to determine if such management strategies could influence the overall success of the seedlings in short-term (2 years) and longer-term (7 years) survival and growth. We hypothesized that $\left(\mathrm{H}_{1}\right) \mathrm{C}$. laciniosa would have the highest survivorship, followed by J. cinerea which may be impacted by disease presence; further, we expected $Q$. rubra to have the lowest survivorship due to its history of low seedling survivorship. We also hypothesized $\left(\mathrm{H}_{2}\right)$ that seedlings planted with tree tubes would exhibit higher survivorship and faster height growth. Finally, we hypothesized $\left(\mathrm{H}_{3}\right)$ that seedlings planted in the spring would have higher survivorship due to the reduced physiological stress.

\section{Materials and Methods}

This experiment took place in Sugarcreek MetroPark forest (circa 200 ha; latitude: 39.617079 longitude: -84.097669$)$, southeast of Dayton, Ohio, USA, with an annual average high temperature of $16^{\circ} \mathrm{C}$ and low of $6{ }^{\circ} \mathrm{C}$ with annual average rainfall of $104.4 \mathrm{~cm}$ (Cox Dayton International Airport Weather Station). This site was a forest that had regenerated following agricultural use and was approximately 80 years old. As of 2011, the forest overstory was dominated by F. americana and 
characterized by populations of Acer negundo, Prunus serotina, Celtis occidentalis, and a suite of minor species including Q. muehlenbergii and Liriodendron tulipera. The understory of this forest had a heavy invasion of L. maackii which was removed by spraying with glyphosate and using a tracked vehicle equipped with a FECON excavator mulcher prior to the beginning of the experiment. Any L. maackii resprouts noted at seedling planting were also removed and sprayed with glyphosate. Overstory Fraxinus dominance was approximately $50 \%$ at the beginning of the experiment; however, mortality due to EAB had already begun and, by the conclusion of the experiment, Fraxinus mortality in the stand was nearly $100 \%$.

Carya laciniosa, J. cinerea, and Q. rubra seeds were collected between August and October of 2011 within a 100-mile radius of Dayton, Ohio, USA. Seeds were germinated in a greenhouse between $21^{\circ} \mathrm{C}$ and $26^{\circ} \mathrm{C}$ and were watered once per day. They were uncovered and assessed for germination once a week for seven weeks. Once seeds germinated, they were placed into cone-shaped containers $(6.4 \mathrm{~cm}$ diameter, $25.4 \mathrm{~cm}$ deep). Seedlings were then placed in a $7^{\circ} \mathrm{C}$ greenhouse and were under automatic irrigation with diluted fertilizer (10-4-3: NPK) for 4 days a week. Flats containing seedlings were moved outside in May 2012 and were either planted in Sugarcreek MetroPark in November 2012 or brought back inside and heeled using wood chips and compost for the winter. Flats brought inside were taken back outside in March 2013 before planting in May 2013.

Within a 5-ha portion of Sugarcreek MetroPark with consistent canopy coverage, 10 plots were haphazardly established for seedling planting. Each of the 10 plots were divided into 2 subplots $(2 \times 2 \mathrm{~m})$, with a $1 \mathrm{~m}$ buffer between subplots where each contained a separate treatment $(n=20)$. Subplots were either planted in November 2012 or in May 2013. In total, 90 seedlings (30 per species) were planted in the fall and another 90 were planted in spring. Five of the 10 plots were randomly selected to have tree seedlings planted with tree tubes, whereas the seedlings in the other 5 plots did not have any type of shelter. Prior to planting, each tree was measured for height and basal diameter and labeled with an embossed zinc tag.

In June 2014, we located and measured the heights of each of the tree seedlings. If the seedling could not be found, it was marked as dead. Again, in March 2019, we conducted similar surveys to measure tree size and survival. We used tree heights at time of planting to calculate the growth rates $(\mathrm{cm} / \mathrm{yr})$ of the trees in both 2014 and 2019. By including measurements at both time points, we assessed the short-term and longer-term response of seedlings to underplanting within the forest. Data from this study are publicly available online [53].

All analyses were conducted in R v.3.5.1 [54]. We used generalized linear models to determine if the survivorship of tree seedlings was predicted by the use of tree tubes using the glm function. We used an ANOVA with $l m$ function to determine if the growth rates of the seedlings were predicted by tree tube use. In order to determine the effect of tree tube use on seedling survival, we used generalized mixed-effects models using the glmer function [55]. We also used a linear mixed effects model to assess how tree tubes affected the growth rates of tree seedlings at both time points, using the lme function [56]. In all mixed-effects models, plot location was used as a random effect since planting season was established as a split-plot design within the tube treatments. We included species as an interaction with either tree tube use or season of planting in each model to determine if a relationship among either of these management strategies was species-specific. Data were visualized using ggplot2 [57].

\section{Results}

Over the seven years of the experiment, there were species-specific patterns of seedling survivorship and growth. In the short term, the survivorships of C. laciniosa $(81.6 \%)$ and J. cinerea $(73.3 \%)$ were significantly higher than Q. rubra $\left(51.6 \% ; \mathrm{z}_{172}=3.762, p<0.001\right)$. At the conclusion of the 7 year experiment, J. cinerea had the highest survivorship rates (23.3\%), followed by C. laciniosa $(18.3 \%)$, and Q. rubra had the lowest survivorship rates (1.6\%). At the end of two years, the median number of C. laciniosa seedlings remaining in each of the 10 plots was 5 out of the 6 originally planted, while J. cinerea had around 4.5 and Q. rubra a little less than 4 remaining seedlings per plot (Figure 1). By the 
conclusion of the experiment, the median value of all three species was $<1$ seedling remaining with Q. rubra represented by only a single seedling left (out of 60 initially planted; Figure 1). Summing across all treatments there were species-specific patterns in seedling growth. After two years, J. cinerea height growth was significantly greater $\left(\mathrm{t}_{101}=4.776, p<0.001\right)$ than either of the other two species (Figure 2, top panel). This pattern persisted for the 7 year sampling with J. cinerea exhibiting higher growth rates than C. laciniosa $\left(\mathrm{t}_{23}=4.24, p<0.001\right.$; Figure 2, bottom panel). After seven years, only one $Q$. rubra seedling survived and had a slower growth rate than the means of any other tree species, but this difference could not be statistically tested.

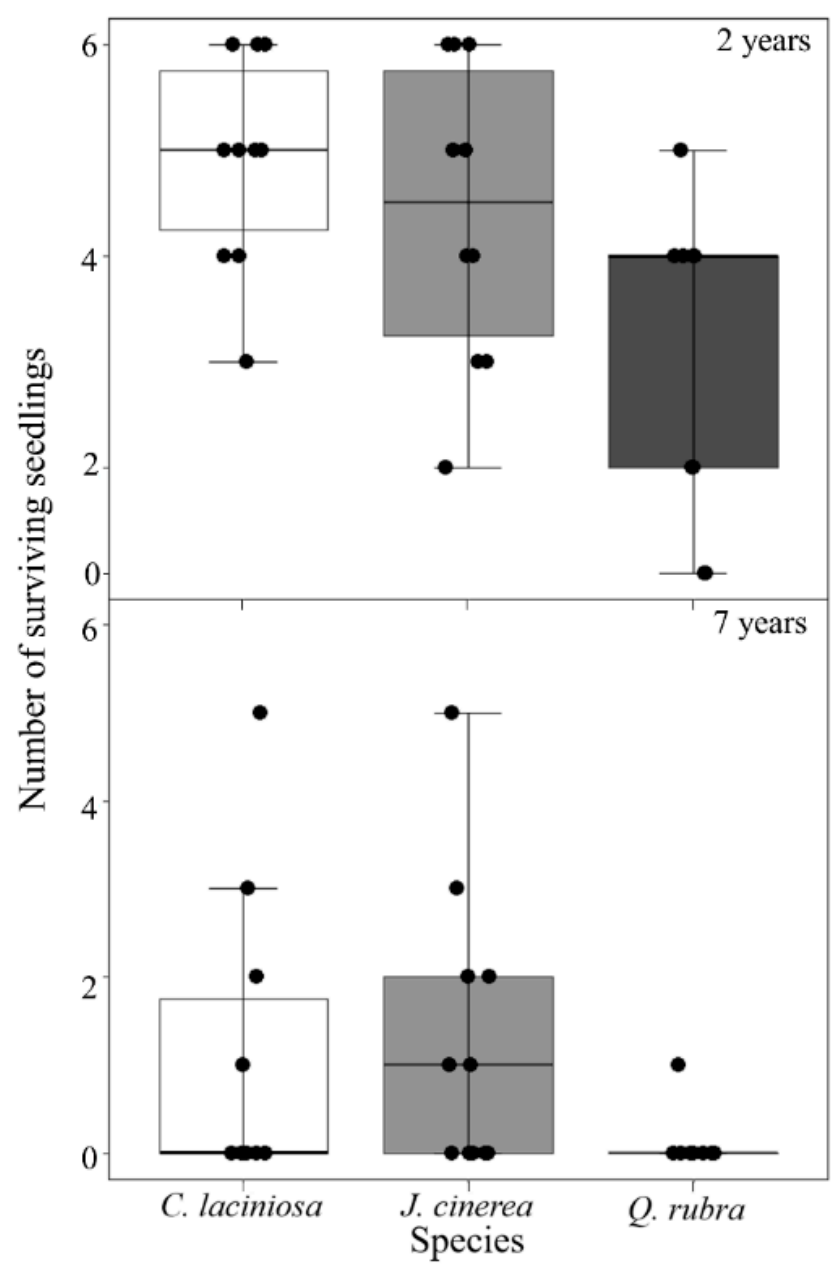

Figure 1. Survivorship of three species of tree seedlings (Carya laciniosa, Juglans cinereal, and Quercus rubra) planted in a temperate forest understory in southwestern Ohio, USA, during a forest restoration experiment. Seedlings were assessed after two and seven years and the maximum number of seedlings possible in each plot was six. The center of each box represents the median and each point represents the number of seedlings in each of ten plots. 


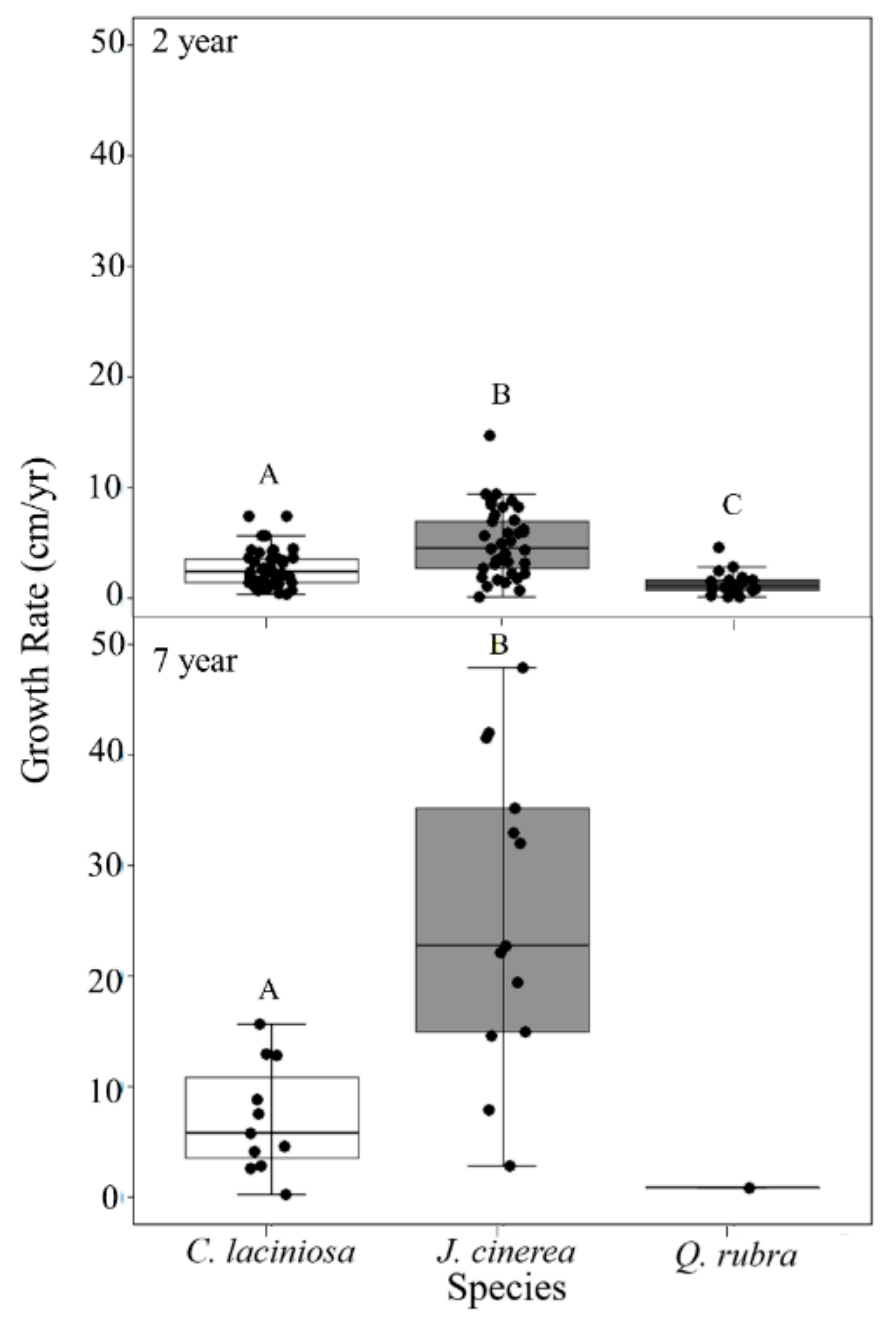

Figure 2. Height growth rate of three species of tree seedlings planted in a temperate forest understory in southwestern Ohio, USA, during a forest restoration experiment. The relative growth rates were calculated at two years and seven years by tree species. The middle bar in the box is the median, individual points represent seedlings, and letters indicate significant differences $(p<0.05)$.

The presence of tree tubes had little influence on tree seedling survivorship or growth over the course of the study. After two years, $Q$. rubra had higher survivorship $\left(\mathrm{z}_{173}=-2.33, p=0.020\right)$ when planted within tubes, while neither $C$. laciniosa nor J. cinerea were affected by shelters ( $p>0.05$; Figure 3$)$. After seven years, only one $Q$. rubra seedling survived, and it was found within a tube. Further, $Q$. rubra had faster growth rates when they were planted within tubes two years after initiation of the study $\left(\mathrm{t}_{18}=-3.63, p=0.002\right.$; Figure 4$)$. Tree tubes did not significantly influence growth rates of $C$. laciniosa or $J$. cinerea seedlings after seven years $(p>0.05)$. 


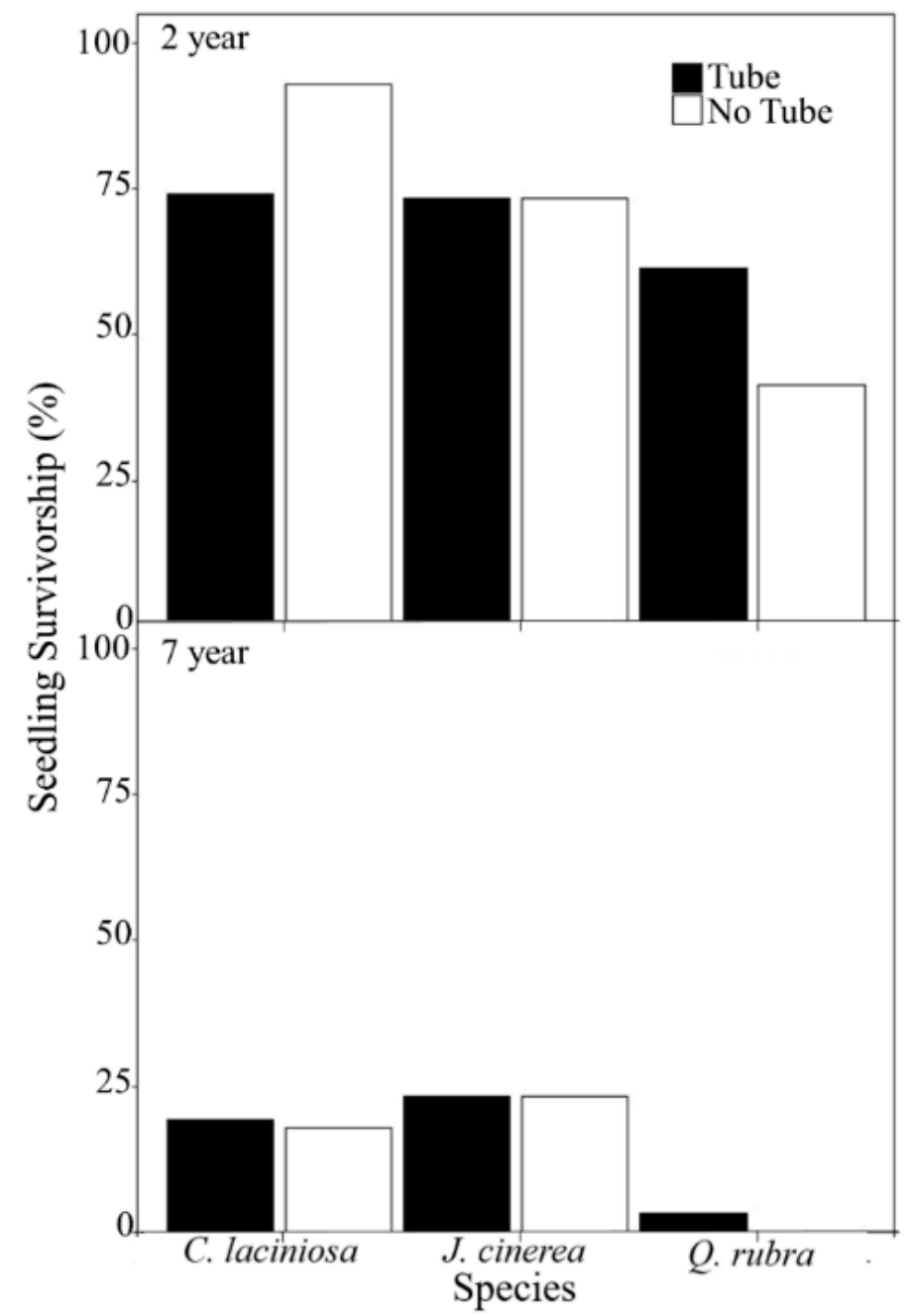

Figure 3. Percentage of seedling survival as a function of tree tubes for three species of tree seedlings planted in a temperate forest understory in southwestern Ohio, USA, during a forest restoration experiment. Seedlings planted without tubes are represented by white bars and trees planted with tubes are represented by black bars. There were no statistical differences among survivorship with or without tree tubes for C. laciniosa or J. cinerea $(p>0.05)$, but $Q$. rubra seedlings had higher survivorship with tree tubes after two years $(p=0.020)$. 


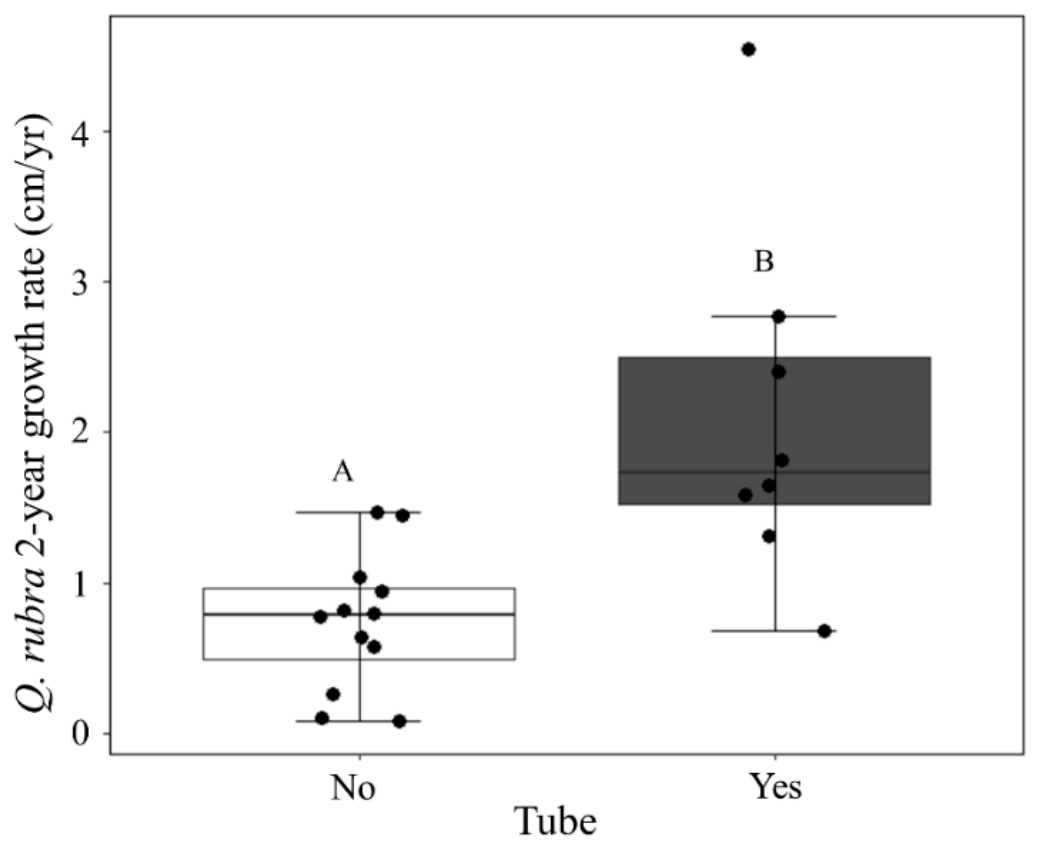

Figure 4. The growth rate of $Q$. rubra seedlings two years after planting by the use of tree tubes for seedlings planted in a temperate forest understory in southwestern Ohio, USA, during a forest restoration experiment. White indicates a lack of tree tube and dark grey indicates the use of tree tubes. Middle line in the box is the median, individual points represent seedlings, and letters represent statistically significant differences in the means $(p=0.002)$.

Planting season was not a strong indicator of the success of seedlings in this study. There was no relationship between survivorship rates of the seedlings and planting season in either 2014 or 2019 $\left(p>0.05\right.$; Figure 5). Season of planting did increase the growth rates of $J$. cinerea in $2019\left(t_{21}=-2.46\right.$, $p=0.022$; Figure 6), but this pattern was not detected for either Q. rubra or C. laciniosa $(p>0.05)$. After seven years of growth, there was only one surviving $Q$. rubra seedling, therefore there was not enough statistical power to predict which variables contributed to its survival or growth rates. 


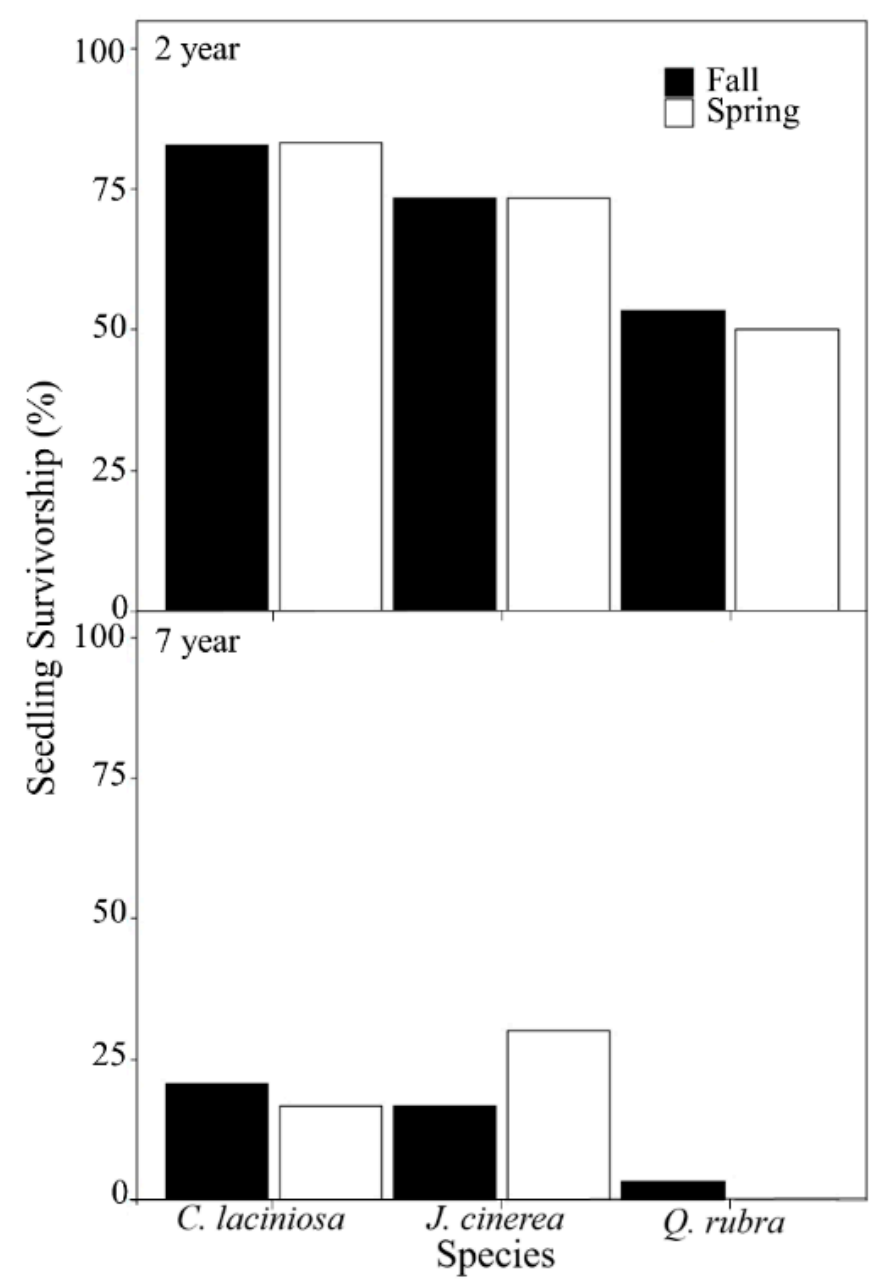

Figure 5. Percent survival of seedlings as a function of planting season for three tree species that were either planted in the fall (black) or the spring (white) in a temperate forest understory in southwestern Ohio, USA, during a forest restoration experiment. There were no statistically significant differences in survivorship among planting seasons for any species after 2 years of growth $(p>0.05)$ or for C. laciniosa or $Q$. rubra after 7 years $(p>0.05)$, but $J$. cinerea seedlings had higher survivorship when planted in the fall after 7 years of growth $(p=0.022)$. 


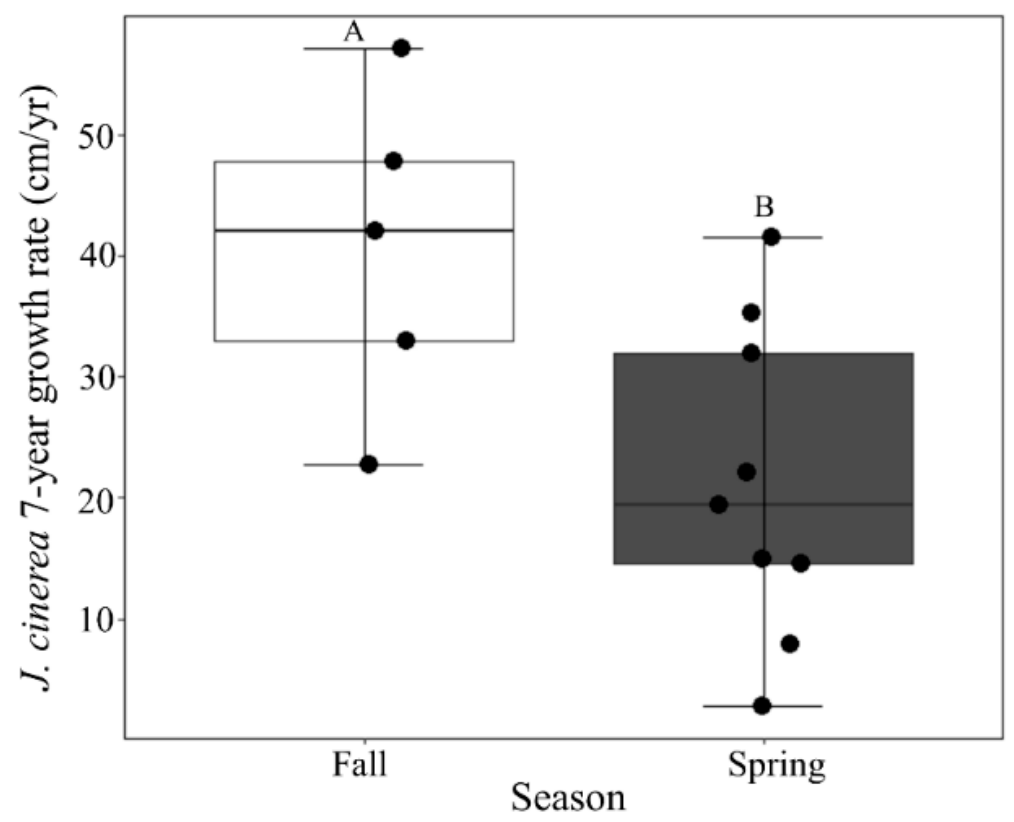

Figure 6. Growth rates of J. cinerea over seven years as measured in 2019 for seedlings planted in a temperate forest understory in southwestern Ohio, USA, during a forest restoration experiment. Seedlings that were planted in the fall are represented by white boxes and growth rates for those planted in spring are represented by the dark grey box. The middle line in the box is the median, individual points represent seedlings, and letters represent statistically significant differences between the means $(p=0.022)$.

\section{Discussion}

Many hardwood forests infested with EAB have incurred a significant loss of canopy trees while also being co-invaded with invasive shrubs that readily inhabit the open niche space created by canopy gaps [30]. Lonicera maackii invasion is a significant concern in many deciduous forests of eastern North America [11] and land managers are increasingly tasked with restoration activities that address the loss of canopy trees due to EAB while simultaneously addressing invasion by L. maackii and other species. Here, we tested the efficacy of planting tree seedlings as a restoration effort following removal of L. maackii and during EAB invasion, using C. laciniosa, J. cinerea, and Q. rubra as replacement tree species. Due to the previous research into the biology of the study species, we hypothesized $\left(\mathrm{H}_{1}\right)$ that $C$. laciniosa would have the highest survivorship followed by J. cinerea with Q. rubra having the lowest survivorship overall. Both C. laciniosa and J. cinerea seedlings had $\sim 20 \%$ survival seven years after planting. In a similar forest, only $\sim 20 \%$ of $J$. nigra seedlings survived for two years following planting [58]. The same study found that $C$. cordiformis seedlings had $\sim 40 \%$ survival after two years, which is considerably lower than our results at two years ( $80 \%$ survival) [58]. One study examining natural regeneration in a similar forest ecosystem found that $<2 \%$ of tree seedlings, including both Carya and Quercus species, survived longer than five years [59]. Thus, the survival rates of both J. cinerea and C. laciniosa planted seedlings were enhanced relative to previous planting attempts and natural regeneration, which suggests that they may be useful species for promoting successful reforestation. Furthermore, J. cinerea had the highest growth rate, and could be better suited for competing with fast growing invasive shrubs for available light. Adding these species to the forest overstory would increase the biodiversity of many regenerating hardwood forests and, if the pathogen is absent, act to conserve J. cinerea trees which face significant population decline due to the butternut canker disease. We found the lowest survivorship in Q. rubra seedlings, consistent with many studies finding lower regeneration of this genus in northern hardwood forests [47,49-51]. Oak species are an important component of the canopy in these forests and regenerating oak trees is a conservation and management goal for our land management partners. Our results suggest that oak reestablishment through seedling 
planting underneath intact dead ash trees may not be effective, even though the area had been cleared of understory competitors prior to planting. It was beyond the scope of our study to assess the cause of mortality in these seedlings; however, we hypothesize that light limitation may be an important factor. Further work is needed to ascertain the appropriate strategy for establishing oak seedlings and allowing promotion into the forest midstory in these forests.

The use of tree tubes is a significant investment for land management agencies and the expectation is that survival and growth of seedlings will be enhanced by their use. We hypothesized $\left(\mathrm{H}_{2}\right)$ that seedlings grown in tree tubes would yield higher growth rates and survivability due to the release from herbivore pressure (particularly that associated with $O$. virginianus). The expensive and time-consuming effort of planting tree seedlings within tree shelters to prevent herbivory has proven necessary in open canopy environments to promote growth and survivorship of many tree species $[40,41,43,60,61]$. Specifically, Q. rubra seedlings planted within tree shelters tend to have faster growth rates and higher survivorship than their unsheltered counterparts [40,41], and we found congruent results in which Q. rubra seedlings had higher survivorship and higher growth rates two years after planting when they were grown in a shelter. After seven years, only one Q. rubra seedlings survived, indicating that protection associated with the tree tube was inconsequential to the longer-term success of this species in our study. Neither C. laciniosa nor J. cinerea growth rates or survivorship were influenced by the use of tree tubes at either measured time point. This is contradictory to previous research that found congenic C. $x$ lecontei had a $30 \%$ higher survival rate when planted with shelters [60]. While the impact of using tree shelters to promote $J$. cinerea seedlings had not been previously tested to our knowledge, there are differing reports for whether shelters aide J. nigra seedlings [43,61], suggesting that other factors may be more important in predicting the success of Juglans species. Overall, we found little evidence that the investment associated with tree shelters influenced survivorship or growth of tree seedlings over the seven-year period of our study, possibly because the seedlings were planted within the forest interior where they were more protected from herbivory. Where very heavy herbivory warrants the use of such shelters, they may be beneficial for $Q$. rubra, but the usefulness of this expensive venture is likely marginal for more herbivore resistant species such as J. cinerea and C. laciniosa.

The timing of tree planting may also predict the success of tree species. We hypothesized $\left(\mathrm{H}_{3}\right)$ that planting tree seedlings in the spring would result in increased success due to the prior research indicating reduced physiological stress and better environmental conditions [32-34]. We found that J. cinerea planted in the fall had faster growth rates than did those planted within the spring when measured after 7 years of growth. However, other researchers found that $J$. nigra seedlings were more successful if planted in the spring [34]. This could indicate that Juglans has species-specific requirements for timing of planting, or perhaps that environmental conditions or handling procedures varied among the studies. Planting season did not change the survivability for any of the seedlings or growth rates for Q. rubra or C. laciniosa in either short- or long-term growth. A previous study found that $Q$. rubra was unaffected by planting season, consistent with our findings [34]. Additionally, we found that planting season did not contribute to the success of $C$. laciniosa. This novel finding for Carya species indicates that $C$. laciniosa seedlings can be planted at the convenience of management teams. Overall, we suggest that land mangers plant J. cinerea in the fall for maximum growth, but in order to maintain the highest survivability these species can be planted in whichever season is the most cost effective, since there was no apparent effect of planting season on overall survivability of any of these tree species.

\section{Conclusions}

In summary, our results suggest that planting seedlings in areas where invasive plant control has taken place and where EAB is impacting on the canopy may be an effective means to introduce species of conservation concern for long-term forest management. Specifically, we found survivorship of C. laciniosa and J. cinerea that was considerably higher than expected for typical forest seedlings suggesting that these species could be effective target replacement species in areas with major Fraxinus 
die-offs where the trees are left intact and there is an increased threat of invasive shrub takeover. The restoration of these species would increase the biodiversity of many regenerating temperate forests of eastern North America. Quercus rubra did not demonstrate an ability to survive these conditions, and more work is needed to understand what conditions might be necessary to advance this species through the seedling stage. Land restoration plans commonly suggest planting tree seedlings in tree shelters to reduce herbivory; however, our results did not suggest any advantage of the shelters for J. cinerea or C. laciniosa, and the temporary apparent benefit to Q. rubra was lost by the end of the study when 29 out of 30 tube-protected seedlings were dead. Planting season was also largely inconsequential to seedling success in our study indicating that land management agencies can either plant in fall, or hold seedlings to spring, depending on what is optimal based on available resources.

Author Contributions: Conceptualization, R.W.M. and M.C.; formal analysis, M.J.W. and R.W.M.; investigation, M.J.W., M.C., K.H., and R.W.M.; resources, M.C. and R.W.M.; data curation, M.J.W., K.H., and R.W.M.; writing—original draft, M.J.W., M.C., and R.W.M.

Funding: This work was supported in part by the University of Dayton Office for Graduate Academic Affairs through the Graduate Student Summer Fellowship Program awarded to M.J.W.

Acknowledgments: We thank Julia Chapman, Sean Goins, Rachel McNeish, and numerous field assistants from the McEwan Lab and Five Rivers Metroparks for helping with the project in various ways. We also thank two anonymous reviewers for their helpful feedback.

Conflicts of Interest: The authors declare no conflict of interest.

\section{References}

1. McEwan, R.; Rhoades, C.; Beiting, S. American Chestnut (Castanea dentata) in the pre-settlement vegetation of Mammoth Cave National Park, Central Kentucky, USA. Nat. Areas J. 2005, 25, 275-281.

2. Parks, A.M.; Jenkins, M.A.; Woeste, K.E.; Ostry, M.E. Conservation status of a threatened tree species: Establishing a baseline for restoration of Juglans cinerea L. in the Southern Appalachian Mountains, USA. Nat. Areas J. 2013, 3333, 413-426. [CrossRef]

3. Schweitzer, C.; Clark, S.L.; Gottschalk, K.W.; Stringer, J.; Sitzlar, R. Proactive restoration: Planning, implementation, and early results of silvicultural strategies for increasing resilience against gypsy moth infestation in upland oak forests on the Daniel Boone National Forest, Kentucky. J. For. 2014, 112, 401-411. [CrossRef]

4. Vose, J.M.; Wear, D.N.; Mayfield, A.E.; Dana Nelson, C. Hemlock woolly adelgid in the southern Appalachians: Control strategies, ecological impacts, and potential management responses. For. Ecol. Manag. 2013, 291, 209-219. [CrossRef]

5. Dukes, J.S.; Pontius, J.; Orwig, D.; Garnas, J.R.; Rodgers, V.L.; Brazee, N.; Cooke, B.; Theoharides, K.A.; Stange, E.E.; Harrington, R.; et al. Responses of insect pests, pathogens, and invasive plant species to climate change in the forests of northeastern North America: What can we predict? This article is one of a selection of papers from NE Forests 2100: A Synthesis of Climate Change Impacts o. Can. J. For. Res. 2009, 39, $231-248$. [CrossRef]

6. Simberloff, D.; Von Holle, B. Positive interactions of nonindigenous species: Invasional meltdown? Biol. Invasions 1999, 1, 21-32. [CrossRef]

7. McEwan, R.W.; Rieske, L.K.; Arthur, M.A. Potential interactions between invasive woody shrubs and the gypsy moth (Lymantria dispar), an invasive insect herbivore. Biol. Invasions 2009, 11, 1053-1058. [CrossRef]

8. Gandhi, K.J.K.; Herms, D.A. Direct and indirect effects of alien insect herbivores on ecological processes and interactions in forests of eastern North America. Biol. Invasions 2010, 12, 389-405. [CrossRef]

9. Wang, R.L.; Yan, W.B.; Quan, G.M.; Liu, S.W.; Zhang, J.E. Effects of light intensity on morphology and physiology of exotic invasive Bidens pilosa L. and non-invasive congener Bidens bipinnata L. Allelopath. J. 2017, 42, 157-168. [CrossRef]

10. Luken, J.O.; Thieret, J.W. Amur Honeysuckle, Its Fall from Grace. Bioscience 1996, 46, 18. [CrossRef]

11. McNeish, R.E.; McEwan, R.W. A review on the invasion ecology of Amur honeysuckle (Lonicera maackii, Caprifoliaceae) a case study of ecological impacts at multiple scales. J. Torrey Bot. Soc. 2016, 143, 367-385. [CrossRef] 
12. Gorchov, D.L.; Trisel, D.E. Competitive effects of the invasive shrub, Lonicera maackii (Rupr.) Herder (Caprifoliaceae), on the growth and survival of native tree seedlings. Plant Ecol. 2003, 166, 13-24. [CrossRef]

13. Hartman, K.M.; McCarthy, B.C. Restoration of a forest understory after the removal of an invasive shrub, Amur honeysuckle (Lonicera maackii). Restor. Ecol. 2004, 12, 154-165. [CrossRef]

14. Runkle, J.R.; DiSalvo, A.; Graham-Gibson, Y.; Dorning, M. Vegetation release eight years after removal of Lonicera maackii in West-Central Ohio. Ohio J. Sci. 2007, 107, 125-129.

15. McNeish, R.E.; Benbow, M.E.; McEwan, R.W. Riparian forest invasion by a terrestrial shrub (Lonicera maackii) impacts aquatic biota and organic matter processing in headwater streams. Biol. Invasions 2012, 14, 1881-1893. [CrossRef]

16. Custer, K.W.; Borth, E.B.; Mahoney, S.D.; McEwan, R.W. Lethal and sublethal effects of novel terrestrial subsidies from an invasive shrub (Lonicera maackii) on stream macroinvertebrates. Freshw. Sci. 2017, 36, 750-759. [CrossRef]

17. Borth, E.B.; Custer, K.W.; McEwan, R.W. Lethal Effects of Leaf Leachate from the Non-Native Invasive Shrub Amur honeysuckle (Lonicera maackii) on a model aquatic organism (Hyalella azteca). Ecoscience 2018, 25, 189-197. [CrossRef]

18. Arthur, M.A.; Bray, S.R.; Kuchle, C.R.; McEwan, R.W. The influence of the invasive shrub, Lonicera maackii, on leaf decomposition and microbial community dynamics. Plant Ecol. 2012, 213, 1571-1582. [CrossRef]

19. Kolbe, S.E.; Townsend-Small, A.; Miller, A.I.; Culley, T.M.; Cameron, G.N. Effect of Lonicera maackii on soil carbon and nitrogen in southwestern Ohio forests. Invasive Plant Sci. Manag. 2015, 8, 375-384. [CrossRef]

20. Poulette, M.M.; Arthur, M.A. The impact of the invasive shrub Lonicera maackii on the decomposition dynamics of a native plant community. Ecol. Appl. 2012, 22, 412-424. [CrossRef]

21. Schuster, M.J.; Dukes, J.S. Non-additive effects of invasive tree litter shift seasonal N release: A potential invasion feedback. Oikos 2014, 123, 1101-1111. [CrossRef]

22. Trammell, T.L.E.; Ralston, H.A.; Scroggins, S.A.; Carreiro, M.M. Foliar production and decomposition rates in urban forests invaded by the exotic invasive shrub, Lonicera maackii. Biol. Invasions 2012, 14, 529-545. [CrossRef]

23. Woods, M.J.; Roberson, E.; Cipollini, D.; Rúa, M.A. White-tailed deer and an invasive shrub facilitate faster carbon cycling in a forest ecosystem. For. Ecol. Manag. 2019, 448, 104-111. [CrossRef]

24. Cipollini, D.; Stevenson, R.; Cipollini, K. Contrasting effects of allelochemicals from two invasive plants on the performance of a nonmycorrhizal plant. Int. J. Plant Sci. 2008, 169, 371-375. [CrossRef]

25. Hutchinson, T.F.; Vankat, J.L. Invasibility and effects of Amur honeysuckle in southwestern Ohio forests. Conserv. Biol. 1997, 11, 1117-1124. [CrossRef]

26. Luken, J.O.; Kuddes, L.M.; Tholemeier, T.C.; Haller, D.M. Comparative responses of Lonicera maackii (Amur honeysuckle) and Lindera benzoin (spicebush) to increased light. Am. Midl. Nat. 1997, 138, 331-343. [CrossRef]

27. Klooster, W.S.; Herms, D.A.; Knight, K.S.; Herms, C.P.; McCullough, D.G.; Smith, A.; Gandhi, K.J.K.; Cardina, J. Ash (Fraxinus spp.) mortality, regeneration, and seed bank dynamics in mixed hardwood forests following invasion by emerald ash borer (Agrilus planipennis). Biol. Invasions 2014, 16, 859-873. [CrossRef]

28. Looney, C.E.; D'Amato, A.W.; Palik, B.J.; Slesak, R.A.; Slater, M.A. The response of Fraxinus nigra forest ground-layer vegetation to emulated emerald ash borer mortality and management strategies in northern Minnesota, USA. For. Ecol. Manag. 2017, 389, 352-363. [CrossRef]

29. Smitley, D.; Davis, T.; Rebek, E. Progression of ash canopy thinning and dieback outward from the initial infestation of emerald ash borer (Coleoptera: Buprestidae) in Southeastern Michigan. J. Econ. Entomol. 2015, 101, 1643-1650. [CrossRef]

30. Hoven, B.M.; Gorchov, D.L.; Knight, K.S.; Peters, V.E. The effect of emerald ash borer-caused tree mortality on the invasive shrub Amur honeysuckle and their combined effects on tree and shrub seedlings. Biol. Invasions 2017, 19, 2813-2836. [CrossRef]

31. Rietveld, W.J. Transplanting stress in bareroot conifer seedlings: Its development and progression to establishment. North. J. Appl. For. 1989, 6, 99-107.

32. McKay, H.M. A review of the effect of stresses between lifting and planting on nursery stock quality and performance. New For. 1997, 13, 369-399. [CrossRef]

33. Ritchie, G.A.; Roden, J.R.; Kleyn, N. Physiological quality of lodgepole pine and interior spruce seedlings: Effects of lift date and duration of freezer storage. Can. J. For. Res. 2007, 15, 636-645. [CrossRef] 
34. Seifert, J.R.; Jacobs, D.F.; Selig, M.F. Influence of seasonal planting date on field performance of six temperate deciduous forest tree species. For. Ecol. Manag. 2006, 223, 371-378. [CrossRef]

35. Waller, D.D.M.; Alverson, W.S.W. The white-tailed deer: A keystone herbivore. Wildl. Soc. Bull. 1997, 25, 217-226.

36. Rooney, T.P.; Waller, D.M. Direct and indirect effects of white-tailed deer in forest ecosystems. For. Ecol. Manag. 2003, 181, 165-176. [CrossRef]

37. Côté, S.D.; Rooney, T.P.; Tremblay, J.-P.; Dussault, C.; Waller, D.M. Ecological impacts of deer overabundance. Annu. Rev. Ecol. Evol. Syst. 2004, 35, 113-147. [CrossRef]

38. Valkonen, S. Survival and growth of planted and seeded oak (Quercus robur L.) seedlings with and without shelters on field afforestation sites in Finland. For. Ecol. Manag. 2008, 255, 1085-1094. [CrossRef]

39. Sharew, H.; Hairston-Strang, A. A comparison of seedling growth and light transmission among tree shelters. North. J. Appl. For. 2005, 22, 102-110.

40. Stange, E.E.; Shea, K.L. Effects of deer browsing, fabric mats, and tree shelters on Quercus rubra seedlings. Restor. Ecol. 1998, 6, 29-34.

41. Sweeney, B.W.; Czapka, S.J. Riparian forest restoration: Why each site needs an ecological prescription. For. Ecol. Manag. 2004, 192, 361-373. [CrossRef]

42. Truax, B.; Gagnon, D.; Fortier, J.; Lambert, F.; Pétrin, M.-A. Ecological factors affecting white pine, red oak, bitternut hickory and black walnut underplanting success in a northern temperate post-agricultural forest. Forests 2018, 9, 499. [CrossRef]

43. Ponder F., Jr.; Ponder, F.; Service, U.F.; Central, N.; Hall, F.; Lincoln, U. Ten-year results of tree shelters on survival and growth of planted hardwoods. North. J. Appl. For. 2003, 20, 104-108.

44. Iverson, L.; Knight, K.S.; Prasad, A.; Herms, D.A.; Matthews, S.; Peters, M.; Smith, A.; Hartzler, D.M.; Long, R.; Almendinger, J. Potential species replacements for black ash (Fraxinus nigra) at the confluence of two threats: Emerald ash borer and a changing climate. Ecosystems 2016, 19, 248-270. [CrossRef]

45. Knott, J.A.; Desprez, J.M.; Oswalt, C.M.; Fei, S. Shifts in forest composition in the eastern United States. For. Ecol. Manag. 2019, 433, 176-183. [CrossRef]

46. Cilles, S.E.; Coy, G.; Stieha, C.R.; Cox, J.J.; Crowley, P.H.; Maehr, D.S. A comparison of seed predation, seed dispersal, and seedling herbivory in oak and hickory: Species with contrasting regenerating abilities in a bluegrass savanna woodland habitat. Northeast. Nat. 2016, 23, 466-481. [CrossRef]

47. Larson, B.C.; Ashton, M.S. Germination and seedling growth of Quercus (section Erythrobalanus) across openings in a mixed-deciduous forest of southern New England, USA. For. Ecol. Manag. 1996, 80, 81-94.

48. McEwan, R.W.; Dyer, J.M.; Pederson, N. Multiple interacting ecosystem drivers: Toward an encompassing hypothesis of oak forest dynamics across eastern North America. Ecography 2011, 34, 244-256. [CrossRef]

49. Meiners, S.J.; Martinkovic, M.J. Survival of and herbivore damage to a cohort of quercus rubra planted across a forest-Old-field edge. Am. Midl. Nat. 2002, 147, 247-255. [CrossRef]

50. Redmond, M.D.; Wilbur, R.B.; Wilbur, H.M. Recruitment and Dominance of Quercus rubra and Quercus alba in a previous Oak-Chestnut Forest from the 1980s to 2008. Am. Midl. Nat. 2012, 168, 427-442. [CrossRef]

51. Nowacki, G.J.; Abrams, M.D. The Demise of Fire and "Mesophication" of Forests in the Eastern United States. Bioscience 2008, 58, 123-138. [CrossRef]

52. Boraks, A.; Broders, K.D. Butternut (Juglans cinerea) health, hybridization, and recruitment in the northeastern United States. Can. J. For. Res. 2014, 44, 1244-1252. [CrossRef]

53. Woods, M.J.; Cobb, M.; McEwan, R.W. Seed and Seedling Data from Sugarcreek Metropark Restoration Experiment. Five Rivers MetroParks Collaboration Data. 2019. Available online: https://ecommons.udayton. edu/mcewanlab_3_data/2/ (accessed on 15 August 2019). [CrossRef]

54. R Core Team R. A Language and Environment for Statistical Computing; R Foundation for Statistical Computing: Vienna, Austria, 2018.

55. Bates, D.; Mächler, M.; Bolker, B.; Walker, S. Fitting Linear mixed-effects models using lme4. J. Stat. Softw. 2015, 67, 1-48. [CrossRef]

56. Pinheiro, J.; Bates, D.; DebRoy, S.; Sarkar, D. R Core Team Nlme: Linear and Nonlinear Mixed Effects Models. R Package version 3.1-138; R Foundation for Statistical Computing: Vienna, Austria, 2017.

57. Wickham, H. Ggplot2 Elegant Graphics for Data Analysis; Springer: Berlin/Heidelberg, Germany, 2009; ISBN 9780387981406. 
58. Hewitt, N.; Kellman, M. Factors influencing tree colonization in fragmented forests: An experimental study of introduced seeds and seedlings. For. Ecol. Manag. 2004, 191, 39-59. [CrossRef]

59. Boerner, R.E.J.; Brinkman, J.A. Ten years of tree seedling establishment and mortality in an Ohio deciduous forest complex. Bull. Torrey Bot. Club 1996, 123, 309-317. [CrossRef]

60. Gravatt, D.A.; Mauney, M. Eight-year effects of plastic tree shelters on planted bottomland hardwood species in northeast Arkansas. Texas J. Sci. 2005, 57, 87-98.

61. Hemery, G.E.; Savill, P.S. The use of treeshelters and application of stumping in the establishment of walnut (Juglans regia). Forestry 2001, 74, 479-489. [CrossRef]

(C) 2019 by the authors. Licensee MDPI, Basel, Switzerland. This article is an open access article distributed under the terms and conditions of the Creative Commons Attribution (CC BY) license (http://creativecommons.org/licenses/by/4.0/). 